\title{
Ummessaoloajan ruokintatason vaikutus lypsylehmien maksan geenitoimintaan
}

Kari Elo ${ }^{1}$, Zohaib Gulzar ${ }^{2}$, Fabian Hoti $^{2}$, Seija Jaakkola ${ }^{1}$, Siru Salin ${ }^{1}$, Mikko Sillanpää ${ }^{3}$, Juhani Taponen $^{4}$, Aila Vanhatalo ${ }^{1}$, Tuomo Kokkonen ${ }^{1}$

${ }^{1}$ Maataloustieteiden laitos, PL 27, 00014 Helsingin yliopisto, ${ }^{2}$ Aalto yliopisto, Perustieteiden korkeakoulu, PL 11000, 00076 Aalto, ${ }^{3}$ Matemaattisten tieteiden laitos ja Biologian laitos, PL 3000, 90014 Oulun yliopisto, ${ }^{4}$ Helsingin yliopisto, Kliinisen tuotantoeläinlääketieteen osasto, 04920 Saarentaus

Ummessaolokaudella kahta kahdeksan ayrshire-lehmän ryhmää ruokittiin joko rajoitetusti tai vapaasti. Lehmät saivat pelkästään säilörehua 6-4 viikkoa ennen odotettua poikimista. Tänä aikana rajoitetusti ruokitut lehmät saivat $100 \%$ (ryhmän keskiarvo $95 \mathrm{MJ} / \mathrm{d}$ ) ja vapaasti ruokitut käytännössä $150 \%$ (keskiarvo $144 \mathrm{MJ} / \mathrm{d}$ ) laskennallisesta energiantarpeestaan. Tunnutusruokinnan alkaessa kolme viikkoa ennen odotettua poikimista, vapaasti ruokitun ryhmän energian saantia alettiin rajoittaa siten, että laskennallinen energian saanti aleni vertailuryhmän tasolle ennustettuun poikimapäivään mennessä. Molempien ryhmien ruokintaan sisältyi kolmen viimeisen tiineysviikon aikana väkirehua $30 \%$ rehuannoksen energiasisällöstä. Tunnutusruokinnan aikana ryhmien energian saannin keskiarvot olivat $107 \mathrm{MJ} / \mathrm{d}$ rajoitetusti ja $135 \mathrm{MJ} / \mathrm{d}$ vapaasti ruokitulla ryhmällä. Poikimisen jälkeen molempien ryhmien ruokinta oli samanlainen. Molemmista ryhmistä jouduttiin poistamaan yksi lehmä ensimmäisellä viikolla poikimisen jälkeen.

Maksanäytteet kerättiin biopsioimalla kahdeksan päivää ennen odotettua poikimista ja yksi ja yhdeksän päivää poikimisen jälkeen. Maksanäytteistä eristettiin kokonais-RNA, jonka laatu analysoitiin sekä elektroforeettisesti että spektrofotometrisesti. Geenitoiminnan kvantitointi tehtiin 32 RNA-näytteestä Affymetrix Bovine GeneChip -siruilla. Näytteenottoajankohtien suhteen näytteet jakautuivat siten, että rajoitetusti ruokittujen ryhmästä analysoitiin 15 näytettä $(5+6+4)$ ja vapaasti ruokitusta ryhmästä 17 näytettä $(5+6+6)$.

Geenitoiminnan voimakkuutta kuvaavien lukujen keskiarvojen kaksinkertaisen keskihajonnan avulla pareittaisista aineistoista valikoitiin $5 \%$ eniten eri tavalla toimivista geeneistä. Empiiristä Bayes-menetelmää käyttävällä t-testillä tehtiin pareittaisia vertailuja, ja tilastollisen merkitsevyyden rajana pidettiin $\mathrm{P}<0,05$. Verrattaessa 8 päivää ennen ja 9 päivää jälkeen poikimisen otettuja näytteitä kontrolliryhmässä havaittiin geenitoiminnan eroja 96 geenissä ja koeryhmässä 39 geenissä. Kummassakin em. ryhmässä yhteisiä geenejä oli 11. Näiden geenien toiminnan muutokset ovat todennäköisesti koekäsittelystä riippumattomia ja liittyvät poikimisen yhteydessä tapahtuviin fysiologisiin muutoksiin. Verrattaessa koe- ja kontrollikäsittelyn välisiä eroja empiiristä Bayesmenetelmää käyttävällä t-testillä havaittiin 54,44 ja 33 geenin toimivan eri tavalla 8 päivää ennen sekä 1 ja 9 päivää jälkeen poikimisen. Hierarkkinen ryhmittely käyttäen Pearson-korrelaatiota jakaa geenit neljään ryhmään sekä 8 päivää ennen että 1 ja 9 päivää jälkeen poikimisen.

Asiasanat: metabolinen stressi, insuliiniresistenssi, energiatasapaino, poikiminen, geenitoiminta, lähetti-RNA, biomarkkerit 


\section{Johdanto}

Lypsylehmillä metabolinen stressi on suurimmillaan poikimisen jälkeen maidontuotannon alkaessa. Metabolinen stressi ilmenee negatiivisen energiatasapainon aikana insuliinin toiminnan ja rasvaaineenvaihdunnan häiriöinä. Maidontuotannon käynnistymisen aiheuttama energiantarpeen lisäys ylittää lehmän syöntikyvyn, jolloin syntyy energiavaje eli energiatasapaino muuttuu negatiiviseksi. Normaalisti energiavaje jatkuu useita viikkoja poikimisen jälkeen (Beam ja Butler 1997, Mäntysaari ja Mäntysaari 2010). Tänä aikana lehmä mobilisoi rasvaa ja valkuaisaineita kudoksistaan.

Rasvan mobilisoinnin seurauksena vapaiden rasvahappojen pitoisuus plasmassa kasvaa. Vapaat rasvahapot hapettuvat joko täydellisesti tai epätäydellisesti ketoaineiksi tai ne varastoidaan triglyserideinä maksaan tai ne käytetään maitorasvan synteesissä. Energiavajeen syvetessä ketoaineiden pitoisuus veressä kasvaa ja samalla hypoglykemia ja insuliinin vajaus syvenevät. Veren insuliinipitoisuuden pieneneminen vähentää ennen kaikkea lihasten ja perifeeristen rasvakudosten glukoosinkäyttöä ja lisää siten glukoosin saatavuutta utareessa ja maidontuotannossa. Veren rasvahappopitoisuuden nousu voimistaa edelleen perifeeristen kudosten insuliiniresistenssiä (Pires ym. 2007) ja todennäköisesti vähentää haiman kykyä erittää insuliinia (Bossaert ym. 2008).

Metabolisella stressillä on osoitettu olevan vaikutusta lehmien sairastumisalttiuteen. Suurin osa lypsylehmän terveysongelmista esiintyy ajanjaksolla kolme viikkoa ennen ja kolme viikkoa jälkeen poikimisen (Drackley 1999). Näistä kuudesta viikosta sairauksien esiintyvyys on suurinta poikimista seuraavan viikon aikana (Ingvartsen ym. 2003).

Voimakas energiavaje ja plasman alhainen insuliinipitoisuus poikimisen jälkeen liittyvät hedelmällisyyden häiriöihin (Beam ja Butler 1997, Bossaert ym. 2008). Ensimmäinen poikimisen jälkeinen ovulaatio tapahtuu sen jälkeen kun energiavajeen aallonpohja on saavutettu (Zurek ym. 1995, Beam ja Butler 1997). Energiavajeen aallonpohja ajoittuu 6-13 päivää poikimisen jälkeen (Beam ja Butler 1997, Mäntysaari ja Mäntysaari 2010). Energiavajeen pitkittyminen ja sen aallonpohjan myöhentyminen siirtävät ensimmäisen poikimisen jälkeisen ovulaation ajankohtaa myöhäisemmäksi viivästyttäen tiinehtymistä ja pidentäen poikimaväliä.

Metabolisella stressillä on ilmeistä yhteyttä myös kuolemantapausten esiintyvyyteen. Epidemiologisissa tutkimuksissa on havaittu, että runsastuottoisimmilla lehmillä on suurin todennäköisyys kuolla alkulaktaation aikana (Miller ym. 2008). McConnel ym. (2010) tekivät kuolemansyytutkimuksen 174 lehmälle, ja he havaitsivat, että lukumääräisesti eniten kuolemantapauksia sattui poikimisen jälkeen energiavajeeseen liittyvistä syistä. Sekä tuotostason yhteys kuolemantapausten esiintyvyyteen että tapausten ajoittuminen viittaavat metabolisen stressin merkitykseen yhtenä kuolemansyynä.

Genomin geenitoiminnan tutkimuksen odotetaan tuovan merkittävää uutta tietoa fysiologisten säätelymekanismien toiminnasta (Smith ym. 2005, Loor ym. 2006, Wathers ym. 2009). Aikaisempi tutkimus on pyrkinyt esimerkiksi analysoimaan kloonauksen vaikutusta alkion varhaisvaiheen geenitoimintaan (Smith ym. 2005), poikimisen ja ruokinnan energiatasojen vaikutusta maksan toimintaan (Loor ym. 2005, Loor ym. 2006), poikimisen vaikutusta utareen geenitoimintaan (Finucane ym. (2008) ja energiavajeen vaikutusta poikimisen jälkeiseen kohdun palautumiseen (Wathers ym. 2009).

Metabolisen stressin aikaansaama sairastumisalttiuden lisääntyminen, hedelmällisyyden heikkeneminen ja kuolemantapausten lisääntyminen aiheuttavat taloudellisia menetyksiä ja heikentävät lehmien hyvinvointia. Metabolisen stressin voimakkuuteen voidaan vaikuttaa ruokinnalla ja hoitokäytännöillä. Aiemmissa tutkimuksissa erityisesti poikimista edeltävä suuri energian saanti on yhdistetty lisääntyneeseen metaboliseen stressiin poikimisen jälkeen (Kokkonen ym. 2005, Nielsen ym. 2010).

Tämä tutkimus on osa laajempaa tutkimushanketta, jossa keskitytään poikimista edeltävän ruokinnan vaikutukseen metaboliseen stressiin ja tämän taustalla oleviin fysiologisiin mekanismeihin. Tutkimuksella pyrimme löytämään fysiologisia mekanismeja ja molekyylitasolla mitattavia ns. biomarkkereita, joilla voi olla yleisempää merkitystä paitsi kotieläinten terveyden ja ruokinnan kehittämisessä myös ihmisen terveyden ja ravitsemuksen näkökulmasta. Tässä artikkelissa esitettävä tutkimus on aineiston ensimmäisestä analysointivaiheesta. Ensimmäisessä vaiheessa tutkimuksen tavoitteena oli löytää ruokinnan energiatasojen ja poikimisen aikaansaamia muutoksia maksan 
geenitoiminnassa. Tämä tutkimus rajoittuu vertailemaan eri tavoin säädeltyjen geenien lukumääriä 8 päivää ennen ja 9 päivää jälkeen poikimisen koe- ja kontrolliryhmien sisällä sekä koe- ja kontrolliryhmien välillä 8 päivää ennen sekä 1 ja 9 päivää jälkeen poikimisen.

\section{Aineisto ja menetelmät}

Lehmäkoe on toteutettu vuosina 2009-2010 Helsingin yliopiston tutkimus- ja opetustilan koenavetassa Viikissä. Kokeessa oli 16 vähintään toisen kertaa poikivaa ayrshire-lehmää. Koe alkoi kuusi viikkoa ennen oletettua poikimispäivää ja päättyi kahdeksan viikkoa poikimisen jälkeen. Ummessaolokauden ajan ja kahden viikon ajan poikimisen jälkeen lehmät pidettiin parsissa, minkä jälkeen ne siirrettiin pihattoon. Ummessaolokauden ajan kahta kahdeksan lehmän ryhmää ruokittiin säilörehulla joko rajoitetusti energian tarpeen mukaisesti (vertailuryhmä) tai vapaasti (koeryhmä). Vapaasti ruokittujen ryhmien päivittäinen säilörehuannos oli noin $150 \%$ laskennallisesta energian tarpeesta poikimista edeltävillä viikoilla 6,5 , ja 4. Koeryhmän säilörehuannosta ryhdyttiin rajoittamaan enenevässä määrin kolme viikkoa ennen odotettua poikimista siten, että laskennallinen energian saanti aleni vertailuryhmän tasolle ennustettuun poikimapäivään mennessä. Tunnutusruokintana lehmät saivat väkirehua $30 \%$ rehuannoksen energiasisällöstä kolmen viikon ajan ennen poikimista.

Poikimisen jälkeen lehmät olivat kokeessa kahden kuukauden ajan, jolloin molempien ryhmien ruokinta oli samanlainen. Koemuoto oli täydellisesti satunnaistettu lohkokoe, jossa lehmät jaettiin pareihin odotetun poikimapäivän ja poikimakerran perusteella ja kunkin parin lehmät arvottiin koeruokinnoille. Geenitoiminnan tutkimista varten lehmiltä kerättiin maksasta biopsioiden näytepalat 8 päivää ennen odotettua poikimista sekä 1 ja 9 päivää poikimisen jälkeen. Näytepalat säilöttiin suojaliuokseen (Allprotect Tissue Reagent, Qiagen $\mathrm{GmbH}$, Hilden, Saksa), ja niitä säilytettiin ensin vuorokausi $+4^{\circ} \mathrm{C}$ :ssa ja sen jälkeen pakastimessa $-20^{\circ} \mathrm{C}$ :ssa.

Kudosnäytepalat homogenisoitiin TissueRuptor-homogenisaattorin (Qiagen GmbH, Hilden, Saksa) avulla ja kokonais-RNA eristettiin RNeasy Plus Mini Kit:n (Qiagen GmbH, Hilden Saksa) menetelmän mukaisesti. Saadun kokonais-RNA:n määrä kvantitoitiin NanoDrop 1000 spektrofotometrilla (Thermo Fisher Scientific, Waltham, MA, USA) ja RNA:n laatu arvioitiin elektroforeesilla käyttäen Agilent 2100 -laitetta ja Agilent RNA 6000 -nanosiruja ja -reagensseja (Agilent Technologies, Santa Clara, CA, USA).

Yhteensä 32 yksilön näytteet analysoitiin geenitoimintasiruilla. Rajoitetusti ruokitusta ryhmästä oli 17 näytettä ja vapaasti ruokitusta ryhmästä 15 näytettä. Näytteiden lukumäärä jakaantui ajankohtiin 8 päivää ennen poikimista sekä 1 ja 9 päivää poikimisen jälkeen seuraavasti: rajoitetusti ruokitut 5, 4 ja 6 ja vapaasti ruokitut 5, 6 ja 6. Geenitoimintasiruina käytettiin Affymetrixin GeneChip ${ }^{\circledR}$ Bovine Genome Array -siruja (Affymetrix Inc., Santa Clara, CA, USA). Siruilla tehtyihin analyyseihin käytettiin 100 ng kokonais-RNA:ta. Kaikkien RNA-näytteiden RIN-arvo oli suurempi kuin 8,9. RNA-näytteiden esikäsittelyt, hybridisointi siruille, sirujen skannaus ja kuvatiedostojen luenta tehtiin Helsingin yliopiston Biomedicum Genomicsin laboratoriossa.

Aineistojen tilastollinen analysointi tehtiin käyttäen R-tilastopaketin ohjelmia (http://www.rproject.org/) sekä Chipster-ohjelmistoa (Kallio ym. 2011). Aineiston laadunarvioinnin jälkeen normalisointi tehtiin RMA-menetelmällä (Irizarry ym. 2003). Geenitoiminnan voimakkuutta kuvaavien lukujen keskiarvojen kaksinkertaisen keskihajonnan avulla pareittaisista aineistoista valikoitiin $5 \%$ eniten eri tavalla toimivista geeneistä. Kahden ryhmän välisten geenitoiminnan erojen tilastollista merkitsevyyttä testattiin empiiristä Bayes-menetelmää hyödyntävällä t-testillä (Smyth 2004) käyttäen raja-arvoina 0,01 ja 0,05. Kaksinkertaisen keskihajonnan avulla valikoitujen geenien aineistoista tehtiin hierarkkinen ryhmittely käyttäen Pearson-korrelaatiota. Ryhmittelyssä käytettiin joko näytteenottoajan perusteella muodostettuja pareja (koenäytteet 8 päivää ennen ja 9 päivää jälkeen poikimisen sekä kontrollinäytteet 8 päivää ennen ja 9 päivää jälkeen poikimisen) tai koe-kontrolli-pareja samalla näytteenottohetkellä (koe-kontrolli-näytteet 8 päivää ennen poikimista ja koekontrollinäytteet 9 päivää poikimisen jälkeen). Ryhmittelyt visualisoitiin UPGMAmenetelmällä piirretyillä dendrogrammeilla sekä geenitoiminnan voimakkuutta kuvaavalla 
graafisella kuvaajalla. Kuvaajassa värit ja niiden intensiteetti kuvaavat geenitoiminnan voimakkuutta, punainen kuvaa voimakasta ja sininen vähäistä geenitoimintaa.

\section{Tulokset ja niiden tarkastelu}

Ensimmäisillä vertailuilla eri tavoin toimivat geenit ryhmiteltiin kahteen ryhmään: geeneihin, joiden toiminta muuttuu poikimisen yhteydessä (1) koekäsittelyn vaikutuksesta ja (2) koekäsittelystä riippumatta. Vertailtaviksi aikapisteiksi valittiin 8 päivää ennen ja 9 päivää jälkeen poikimisen. Koe- ja kontrolliryhmien kaksinkertaisen keskihajonnan avulla valikoitujen geenien aineistoja vertailtiin erikseen. Empiiristä Bayes-menetelmää käyttävällä ttestillä tehtiin pareittaisia vertailuja, ja tilastollisen merkitsevyyden rajana pidettiin $\mathrm{P}<0,05$. Verrattaessa 8 päivää ennen ja 9 päivää jälkeen poikimisen otettuja näytteitä kontrolliryhmässä havaittiin geenitoiminnan eroja 96 geenissä ja koeryhmässä 39 geenissä. Pareittaisessa vertailussa yhteensä 11 geenin toiminnassa oli eroja sekä koe- että kontrolliryhmässä (Taulukko 1). Näiden geenien toiminnan muutoksia voidaan pitää koekäsittelystä riippumattomina.

Taulukko 1. Pareittaisessa vertailussa sekä koe- että kontrolliryhmästä löytyi 11 saman geenin säätelyssä eroja vertailtaessa 8 päivää ennen ja 9 päivää jälkeen poikimisen kerättyjä näytteitä.

\begin{tabular}{llll}
\hline Geeni & Geenin lyhenne & $\begin{array}{l}\text { Riskitaso } \\
\text { (koe } \\
-8 \text { vs. 9 pv) }\end{array}$ & $\begin{array}{l}\text { Riskitaso } \\
\text { (kontrolli } \\
-8 \text { vs. 9pv) }\end{array}$ \\
\hline apolipoproteiini A-1 & & 0,0050 & 0,0301 \\
solutukirankaan liittyvä proteiini 4 & APOA1 & 0,0044 & 0,0422 \\
3-hydroksyyli-3-metyyliglutaryyli-CoA reduktaasi & CKAP4 & 0,0002 & 0,0151 \\
3-hydroksyyli-3-metyyliglutaryyli-CoA syntaasi 1 & HMGCS1 & 0,0005 & 0,0485 \\
insuliinin kaltaisen kasvutekijän sitojaproteiini 2 & IGFBP2 & 0,0005 & 0,0088 \\
hypoteettinen proteiini LOC100270756 & LOC100270756 & 0,0011 & 0,0103 \\
kationinen trypsiini & LOC780933 & 0,0092 & 0,0178 \\
metioniini adenosyylitransferaasi II, alfa & MAT2A & 0,0061 & 0,0048 \\
pyruvaattikarboksilaasi & PC & 0,0011 & 0,0142 \\
proteiinityrosiinifosfataasireseptori, tyyppi D & PTPRD & 0,0094 & 0,0106 \\
sulfiredoksiini 1 & SRXN1 & 0,0092 & 0,0444 \\
\hline
\end{tabular}

Verrattaessa koe- ja kontrollikäsittelyn välisiä eroja empiiristä Bayes-menetelmää käyttävällä ttestillä havaittiin 54, 44 ja 33 geenin toimivan eri tavalla 8 päivää ennen sekä 1 ja 9 päivää jälkeen poikimisen. Hierarkkinen ryhmittely käyttäen Pearson-korrelaatiota jakaa geenit neljään ryhmään sekä 8 päivää ennen että 1 ja 9 päivää jälkeen poikimisen. Hierarkkisen ryhmittelyn tulos 8 päivää ennen poikimista otettujen koe- ja kontrolliryhmän näytteiden välillä näkyy kuvassa 1 . 


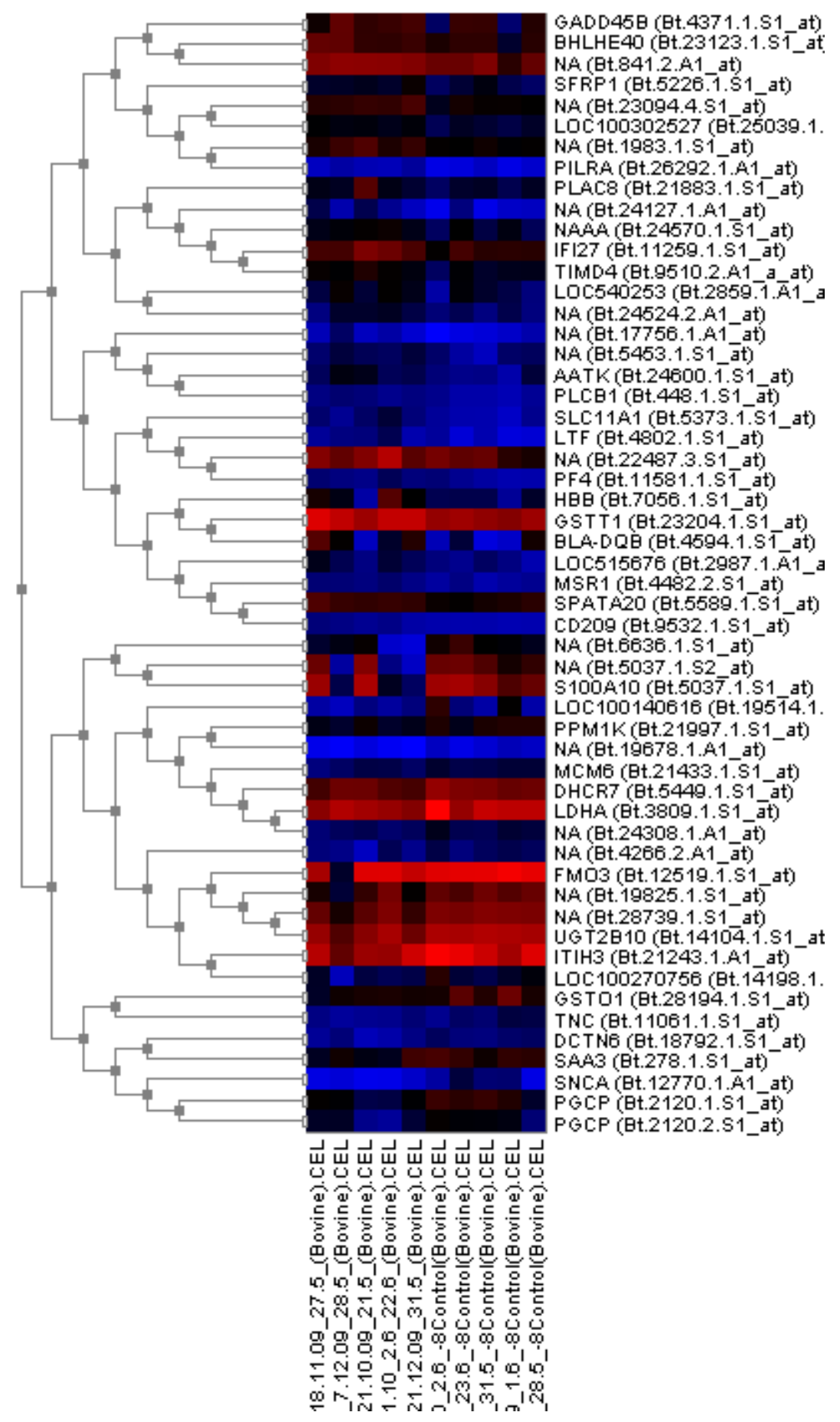

Kuva 1. Hierarkkisen ryhmittelyn tulos 8 päivää ennen poikimista otettujen koe- ja kontrolliryhmän näytteiden välillä. Kuvan x-akselilla ovat RNA-näytteet, viisi koe- ja viisi kontrolliryhmän näytettä. Kuvassa näkyvistä geeneistä tilastollisesti merkitsevin ero koe- ja kontrolliryhmän välillä oli alfasynukleiinilla (SNCA) 0,00162.

Huomattavan samanlaisella koejärjestelyllä maksan geenitoimintaa on aiemmin analysoitu kahdessa tutkimuksessa (Loor ym. 2005, 2006; McCarthy ym. 2010). Loor ym. (2005) ja Loor ym. (2006) tutkivat poikimista edeltävän ruokinnan energiatason vaikutusta holstein-rotuisilla lypsylehmillä. Kokeessa oli kaksi neljän lehmän ryhmää, toista ruokittiin ad libitum ja toisen ryhmän energiansaanti oli noin 80 \% laskennallisesta energiantarpeesta. Loor ym. (2005) ja Loor ym. (2006) 
keräsivät maksasta kudosnäytepaloja $-65,-30,-14,+1,+14,+28$ ja +48 päivää ennen ja jälkeen poikimisen ja analysoivat maksassa toimivien yli 6300 geenin toimintaa cDNA geenitoimintasiruilla. He löysivät 62 geeniä, joiden toiminnassa oli ajallista eroa poikimisen läheisyydessä (Loor ym. 2005). Yhteensä 85 geenin toiminta muuttui ajan suhteen eri tavalla eri energiatasoilla ja 122 geenin toimintaan vaikutti pelkästään poikimista edeltävän ruokinnan energiataso (Loor ym. 2006). Merkittävin ero tämän ja Loorin ym. (2005, 2006) ryhmän tutkimusten välillä on geenitoimintasirussa, minkä takia tuloksia ei voi suoraan verrata. McCarthy ym. (2010) tutkivat kahta 12 lypsylehmän ryhmää, joista toisen ryhmän lehmillä oli lievä ja toisen ryhmän lehmillä vakava energiavaje. Lehmät teurastettiin kaksi viikkoa poikimisen jälkeen, ja samassa yhteydessä otettiin maksanäyte geenitoiminnan tutkimusta varten. McCarthyn ym. (2010) tutkimuksessa käytettiin samaa Affymetrixin sirua kuin tässä tutkimuksessa. McCarthy ym. (2010) havaitsivat 416 geenin toiminnassa eroja kahden ryhmän välillä.

Tässä tutkimuksessa havaittiin vähemmän eroja maksan geenitoiminnassa koe- ja vertailuryhmän välillä kuin aiemmissa tutkimuksissa (Loor ym. 2005, 2006, McCarthy ym. 2010). Erot saattavat selittyä sillä, että meidän tutkimuksessamme ryhmien välinen energiatase-ero oli pienempi kuin aiemmissa tutkimuksissa. Lisäksi me käytimme erilaista geenitoimintasirua kuin Loorin ym. (2005, 2006) tutkimuksissa ja näytteenoton ajankohta on erilainen kuin McCarthy ym. (2010) tutkimuksessa.

Tämän tutkimuksen seuraavassa vaiheessa selvitetään eri tavoin toimivien geenien mahdollista roolia metabolisen stressin synnyssä sekä varmistetaan tärkeimmät geenitoimintasiruilla saadut tulokset kvantitatiivisen PCR:n avulla. Viimeisessä vaiheessa yhdistetään geenitoiminnan ja fysiologian osa-alueilla tehtyjen mittausten aineistot.

\section{Johtopäätökset}

Verrattaessa 8 päivää ennen ja 9 päivää jälkeen poikimisen otettuja koe- ja kontrollinäytteitä havaittiin maksan geenitoiminnan eroja 39 ja 96 geenissä. Poikimista edeltävän ruokinnan rajoittamisella oli vaikutusta geenitoimintaan: verrattaessa koe- ja kontrollikäsittelyn välisiä eroja havaittiin 54,44 ja 33 geenin toimivan eri tavalla 8 päivää ennen sekä 1 ja 9 päivää jälkeen poikimisen.

\section{Kirjallisuus}

Beam, S.W. \& Butler, W.R. 1997. Energy balance and ovarian follicle development prior to the first ovulation postpartum in dairy cows receiving three levels of dietary fat. Biology of Reproduction 56: 133-142.

Bossaert, P., Leroy, J.L.M.R., De Vliegher, S. \& Opsomer, G. 2008. Interrelations between glucose-induced insulin response, metabolic indicators, and time of first ovulation in high-yielding dairy cows. Journal of Dairy Science 91: 3363-3371.

Drackley, J.K. 1999. Biology of dairy cows during the transition period: the final frontier ? Journal of Dairy Science 82: 2259-2273.

Finucane, K.A., McFadden, T.B., Bond, J.P., Kennelly, J.J. \& Zhao, F-Q. 2008. Onset of lactation in the bovine mammary gland: gene expression profiling indicates a strong inhibition of gene expression in cell proliferation. Functional \& Integrative Genomics 8: 251-264.

Ingvartsen, K.L., Dewhurst, R.J. \& Friggens, N.C. 2003. On the relationship between lactational performance and health: is it yield or metabolic imbalance that cause production diseases in dairy cattle ? A position paper. Livestock Production Science 83: 277-308.

Irizarry, R.A., Hobbs, B., Collin, F., Beazer-Barclay, Y.D., Antonellis, K.J., Scherf, U. \& Speed, T.P. 2003. Exploration, normalization, and summaries of high density oligonucleotide array probe level data. Biostatistics 4:249-264. 
Kallio, M.A., Tuimala, J.T., Hupponen, T., Klemelä, P., Gentile, M., Scheinin, I., Koski, M., Käki, J. \& Korpelainen, E.I. 2011. Chipster: user-friendly analysis software for microarray and other high-throughput data. BMC Genomics 12: 507.

Kokkonen, T., Taponen, J., Anttila, T., Syrjälä-Qvist, L., Delavaud, C., Chilliard, Y., Tuori, M. \& Tesfa, A.T. 2005. Effect of body fatness and glucogenic supplement on lipid and protein mobilization and plasma leptin in dairy cows. Journal of Dairy Science 88: 1127-1141.

Loor, J.J., Dann, H.M., Everts, R.E., Oliveira, R., Green, C.A., Guretzky, N.A., Rodriguez-Zas, S.L., Lewin, H.A. \& Drackley, J.K. 2005. Temporal gene expression profiling of liver from periparturient dairy cows reveals complex adaptive mechanisms in hepatic function. Physiological Genomics 23: 217-226.

Loor, J.J., Dann, H.M., Janovick Guretzky, N.A., Everts, R.E., Oliveira, R., Green, C.A., Litherland, N.B., Rodriguez-Zas, S.L. Lewin, H.A. \& Drackley, J.K. 2006. Plane of nutrition prepartum alters hepatic gene expression and function in dairy cows as assessed by longitudinal transcript and metabolic profiling. Physiological Genomics 27: 29-41.

McCarthy, S.D., Waters, S.M., Kenny, D.A., Diskin, M.G., Fitzpatrick, R., Patton, J., Wathes, D.C., \& Morris, D.G. 2010. Negative energy balance and hepatic gene expression patterns in high-yielding dairy cows during the early postpartum period: a global approach. Physiological Genomics 42A:188-199.

McConnel, C.S., Garry, F.B., Hill, A.E., Lombard, J.E., \& Gould, D.H. 2010. Conceptual modeling of postmortem evaluation findings to describe dairy cow deaths. Journal of Dairy Science 93: 373-386.

Miller, R.H., Kuhn, M.T., Norman, H.D. \& Wright, J.R. 2008. Death losses for lactating cows in herds enrolled in dairy herd improvement test plans. Journal of Dairy Science 91: 3710-3715.

Mäntysaari, P. \& Mäntysaari, E.A. 2010. Predicting early lactation energy balance in primiparous Red Dairy Cattle using milk and body traits. Acta Agriculturae Scandinavica Section A 60: 79-87.

Nielsen, A. Hameleers, A., Young, F.J., Larsen, T. \& Friggens, N.C. 2010. Energy intake in late gestation affects blood metabolites in early lactation independently of milk production in dairy cows. Animal 4: 52-60.

Paradis, E., Claude, J. \& Strimmer, K. 2004. APE: analyses of phylogenetics and evolution in R language. Bioinformatics 20: 289-290.

Pires, A.A.J., Souza, A.H. \& Grummer, R.R. 2007. Induction of hyperlipidemia by intravenous infusion of tallow emulsion causes insulin resistance in holstein cows. Journal of Dairy Science 90: 2735-2744.

Smith, S.L., Everts, R.E., Tian, X.C. Du, F., Sung, L-Y., Rodriguez-Zas, S.L., Jeong,, B-S., Renard, J-P., Lewin, H.A. \& Yang, X. 2005. Global gene expression profiles reveal significant nuclear reprogramming by the blastocyst stage after cloning. Proceedings of the National Academy of Sciences of the United States of America 102: 17582-17587.

Smyth, G. K. 2004. Linear models and empirical Bayes methods for assessing differential expression in microarray experiments. Statistical Applications in Genetics and Molecular Biology, Vol. 3, No. 1, Artikkeli 3.

Wathers, D.C., Cheng, Z., Chowdhury, W., Fenwick, M.A., Fitzpatrick, R. Morris, D.G., Patton, J. \& Murhpy, J.J. 2009. Negative energy balance alters global gene expression and immune response in the uterus of postpartum dairy cows. Physiological Genomics 39:1-13.

Zurek, E., Foxcroft, R. \& Kennelly, J.J. 1995. Metabolic status and interval to first ovulation. Journal of Dairy Science 78: 1909-1920. 